\title{
IncP-1 1 plasmids are important vectors of antibiotic resistance genes in agricultural systems: diversification driven by class 1 integron gene cassettes
}

\author{
Holger Heuer ${ }^{1}$, Chu T. T. Binh ${ }^{1+}$, Sven Jechalke ${ }^{1}$, Christoph Kopmann ${ }^{1}$, Ute Zimmerling ${ }^{1}$, \\ Ellen Krögerrecklenfort ${ }^{1}$, Thomas Ledger ${ }^{2}$, Bernardo González ${ }^{2}$, Eva Top ${ }^{3}$ and Kornelia Smalla ${ }^{1}$ * \\ Federal Research Centre for Cultivated Plants, Institute for Epidemiology and Pathogen Diagnostics, Julius Kühn-Institut, Braunschweig, Germany \\ 2 Department de Ciencias Biológicas, Universidad Adolfo Ibañez, Santiago, Chile \\ ${ }^{3}$ Department of Biological Sciences, Institute for Bioinformatics and Evolutionary Studies, University of Idaho, Moscow, ID, USA
}

\section{Edited by:}

Rustam I. Aminov, University of Aberdeen, UK

Reviewed by:

Henning Sørum, Norwegian School of Veterinary Science, Norway

Yixin Shi, Arizona State University,

USA

Peter Norberg, University of

Gothenburg, Sweden

*Correspondence:

Kornelia Smalla, Julius Kühn-Institut,

Institute for Epidemiology and

Pathogen Diagnostics, Messeweg

11-12, D-38104 Braunschweig,

Germany.

e-mail: kornelia.smalla@jki.bund.de

\section{${ }^{+}$Present address:}

Chu T. T. Binh, Department of Biology, Loyola University Chicago, 1032 West Sheridan Road, Chicago, IL 60660, USA.

\begin{abstract}
The role of broad-host range IncP- $1 \varepsilon$ plasmids in the dissemination of antibiotic resistance in agricultural systems has not yet been investigated. These plasmids were detected in total DNA from all of 16 manure samples and in arable soil based on a novel $5^{\prime}$-nuclease assay for real-time PCR. A correlation between IncP-1 $1 \varepsilon$ plasmid abundance and antibiotic usage

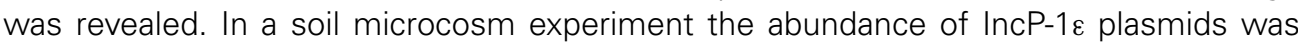
significantly increased even 127 days after application of manure containing the antibiotic compound sulfadiazine, compared to soil receiving only manure, only sulfadiazine, or water. Fifty IncP-1 $1 \varepsilon$ plasmids that were captured in E. coli CV601 gfp from bacterial communities of manure and arable soil were characterized by PCR and hybridization. All plasmids carried class 1 integrons with highly varying sizes of the gene cassette region and the sul 1 gene. Three IncP-1 $1 \varepsilon$ plasmids captured from soil bacteria and one from manure were completely sequenced. The backbones were nearly identical to that of the previously described IncP-1 $\varepsilon$ plasmid pKJK5. The plasmids differed mainly in the composition of a Tn402-like transposon carrying a class 1 integron with varying gene cassettes, IS1326, and in three of the plasmids the tetracycline resistance transposon $T n 1721$ with various truncations. Diverse Betaand Gammaproteobacteria were revealed as hosts of one of the IncP-1 $\varepsilon$ plasmids in soil microcosms. Our data suggest that IncP-1 $\varepsilon$ plasmids are important vectors for horizontal transfer of antibiotic resistance in agricultural systems.
\end{abstract}

Keywords: IncP-1ع plasmid, exogenous isolation, complete sequence, gene cassette, qPCR, arable soil, pig manure

\section{INTRODUCTION}

Spreading manure on agricultural soils was recently shown to promote spreading of transferable antibiotic resistances and residual veterinary medicines in agricultural soils (reviewed in Schauss et al., 2009; Heuer et al., 2011). Frequencies at which sulfadiazine (SDZ) resistance plasmids were captured from soil bacteria into E. coli were found to be higher for soils treated with manure than for soils that did not receive manure (Heuer and Smalla, 2007). Treatment of soil with manure spiked with SDZ resulted in significantly higher transfer frequencies compared to non-spiked manure (Heuer and Smalla, 2007). A survey of field-scale manure slurries used for soil fertilization revealed that antibiotic resistance plasmids could easily be captured into E. coli from the different manures (Binh et al., 2008). A large proportion of the plasmids could be assigned to known plasmid groups by DNA-hybridization and PCR. Remarkably, 13 of the plasmids captured gave a strong PCR product with primers targeting the $\operatorname{trf} A$ gene of IncP-1 plasmids (Götz et al., 1996) but did not hybridize with the probes derived from the two reference plasmids RK2 (IncP- $1 \alpha$ ) and R751 (IncP-1 $\beta$ ). The trfA PCR products were cloned and sequenced and shown to be almost identical to the recently sequenced IncP- $1 \varepsilon$ plasmid pKJK5 (Binh et al., 2008).
Plasmids of the IncP-1 group are considered as one of the best studied plasmid groups. For decades, plasmids belonging to this incompatibility group have attracted the attention of molecular biologists and ecologists because of their efficient conjugative transfer to and their stable replication in a wide range of Gramnegative bacteria (Thomas, 2000). IncP-1 plasmids were originally designated as clinical plasmids because the prototype IncP- $1 \alpha$ plasmid RK2 and the IncP-1 $\beta$ plasmid R751 were originally isolated from clinical strains (Pansegrau et al., 1994; Thorsted et al., 1998). The complete sequences of these two plasmids enabled the development of a PCR-based plasmid detection system (Götz et al., 1996) that virtually replaced the older hybridization method using incompatibility group-specific probes (Couturier et al., 1988). This greatly facilitated the detection of IncP-1 specific sequences not only in isolated strains and plasmids but also in microbial community DNA directly extracted from diverse environments. While earlier characterization of a few catabolic IncP-1 plasmids had already shown that IncP-1 plasmids occur in environmental as well as clinical isolates, only PCR-based detection in combination with Southern blot hybridization revealed that these plasmids were certainly not confined to the clinical environment but instead were frequently found in various environments such as soil, sediments, 
sewage, or manure (Götz et al., 1996; Heuer et al., 2002). Often the abundance of populations carrying these plasmids seemed to be related to pollution (Smalla et al., 2000, 2006). Based on comparative genomics, the basic structure of the first set of described IncP-1 plasmids has been confirmed for many others by now (Schlüter et al., 2007; Sen et al., 2011). Besides their backbone functions for vegetative replication, stable maintenance, and transfer the accessory genes, that are typically found in between the blocks of backbone functions at up to three regions of insertion, confer resistances to nearly all clinically important classes of antimicrobial drugs, quaternary ammonium compounds, and mercury resistances or encode degradation of man-made compounds. However, the increasing number of completely sequenced IncP-1 plasmids also showed that there are additional groups of IncP-1 plasmids that clearly differ in their backbone from the IncP- $1 \alpha$ and the IncP- $1 \beta$ plasmids. Thus novel subgroups often represented by one plasmid at the time have been proposed (Vedler et al., 2004; Haines et al., 2006; Bahl et al., 2007). Since these plasmids were too divergent in genome sequence from the IncP- $1 \alpha$ and IncP- $1 \beta$ plasmids to be detected by means of the primer systems developed by Götz et al. (1996), new primer systems for detection of IncP-1 plasmids were published by Bahl et al. (2009) to encompass at least the known diversity of IncP-1 plasmids. The environmental distribution of the recently discovered IncP-1 subgroups is not well explored yet.

In the present study we aimed to explore the abundance of IncP- $1 \varepsilon$ plasmids and their role in dissemination of antibiotic resistance genes in the agro-ecosystem. A real-time PCR system was established to provide quantitative data on the abundance of populations carrying IncP- $1 \varepsilon$ plasmids in manure slurries and in agricultural soils, and how this correlates with selective pressure by antibiotics. We report on the characterization of 50 plasmids exogenously captured from manure, bulk, and rhizosphere soil samples of independent micro-, and mesocosms

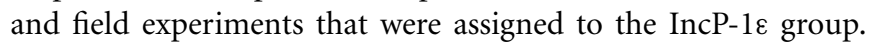
The host range of one of the plasmids was determined in a soil microcosm experiment. The complete genome sequences of four IncP-1 $1 \varepsilon$ plasmids were analyzed and compared to the prototype pKJK5. As all four IncP-1 $1 \varepsilon$ plasmids contained class 1 integrons we hypothesized that antibiotic resistance gene cassettes might drive the diversification of IncP- $1 \varepsilon$ plasmids. To prove this hypothesis all exogenously captured plasmids assigned to the IncP- $1 \varepsilon$ group were analyzed for the presence of class 1 integron gene cassettes and the size of the gene cassettes integrated.

\section{MATERIALS AND METHODS SAMPLES AND PLASMID CAPTURE}

Soil microcosm experiments were set up to investigate the effects of manure and SDZ on the abundance of antibiotic resistance plasmids. For each microcosm, $2 \mathrm{~kg}$ of top soil from an arable field near Kaldenkirchen, Germany [Gleyic Cambisol, 3.6\% clay, 23.1\% silt, $73.3 \%$ sand, $\mathrm{pH}\left(\mathrm{CaCl}_{2}\right)$ 5.5, organic C $1.7 \%$, maximal water holding capacity 27\%] was mixed either with $80 \mathrm{~g}$ manure slurry or water (both either with or without addition of $16 \mathrm{mg} \mathrm{SDZ}$ and $16 \mathrm{mg}$ acetyl-SDZ), and adjusted to $30 \%$ of the maximum water holding capacity. For each of these four treatments, four replicate microcosms per sampling time (29, 57, 127 days after treatment) were prepared and incubated at $10^{\circ} \mathrm{C}$ in the dark. The agricultural soils (silty sand; sandy loam; silt) that were not fertilized with manure for more than 10 years, originated from an experimental plot in Großbeeren (Germany).

The plasmids analyzed in the present study were obtained from manure (Heuer et al., 2002; Binh et al., 2008) and soil from an independent microcosm (Heuer and Smalla, 2007), mesocosm, and field experiments. Capture of plasmids from soil bacteria in the plasmid-free rifampicin resistant E. coli CV601 gfp recipient was done as previously described (Binh et al., 2007). Briefly, soil was shaken with glass beads for $2 \mathrm{~h}$ in 1:10 diluted Tryptic Soy Broth (BD Diagnostic Systems, Heidelberg, Germany) at $20^{\circ} \mathrm{C}$, and mixed with $E$. coli cells. Coarse particles were settled out, cells from supernatants were pelleted and transferred to a membrane filter on Plate Count Agar (PCA; Merck, Darmstadt, Germany). After overnight incubation at $28^{\circ} \mathrm{C}$, the suspended mating mixtures were spread plated on Mueller-Hinton agar NCCLS (Merck) supplemented with SDZ and rifampicin to select for transconjugants that captured a sulfonamide resistance plasmid. Plasmid pKS77 was obtained from pig manure as previously described (Heuer et al., 2002). Plasmid pKJK5 was kindly provided by the group of S. Sørensen, University of Copenhagen.

\section{PLASMID ISOLATION AND CHARACTERIZATION BY PCR AND SOUTHERN BLOT ANALYSIS}

Plasmid DNA was isolated from cell pellets harvested from colonies freshly grown on PCA using the Qiagen plasmid isolation kit. Restriction enzyme digestion of plasmid DNA, Southern blotting, and hybridization were done as described by Binh et al, (2008). The digoxigenin-labeled trfA probe was generated from PCR products obtained with the primers described by Bahl et al. (2009) from pKJK5. The intI1 gene derived probes were generated by digoxigenin labeling of PCR products obtained from Salmonella enterica AM237806. Primers targeting intI1, and PCR conditions were as described by Moura et al. (2010). The aadA probe used was a mixed probe generated from aadA1, aadA2, aadA9, and aadA13 (Binh et al., 2009). The plasmid DNA was analyzed for the presence of the sull gene (Heuer and Smalla, 2007) and of IncP-1ع trfA (this study) by real-time PCR.

\section{HOST RANGE STUDY}

The host range of the IncP- $1 \varepsilon$ plasmids pHH3414 in rhizosphere soil was determined by introducing E. coli CV601gfp pHH3414 $\left(\sim 1 \times 10^{6}\right.$ colony forming units per gram of soil) into soil microcosms planted with Acacia caven. The soil was previously treated with manure. After 4 weeks, serial 10 -fold dilutions of rhizosphere and bulk soil in sterile saline were plated onto MuellerHinton agar NCCLS (Merck) supplemented with cycloheximide (100 $\left.\mathrm{mg} \mathrm{l}^{-1}\right)$, tetracycline $\left(5 \mathrm{mgl}^{-1}\right), \mathrm{SDZ}\left(100 \mathrm{mgl}^{-1}\right)$, and streptomycin $\left(50 \mathrm{mgl}^{-1}\right)$ for selection of putative transconjugants (recipients of plasmid pHH3414). Gfp negative colonies grown on selective media for transconjugants were picked, re-streaked, and cell lysates were screened by IncP-1ع PCR. The genomic and plasmid DNA extracted from transconjugants (IncP-1ع PCR positive colonies) were further characterized by BOX-PCR and SphI 
plasmid restriction digests, respectively, as previously described (Smalla et al., 2006).

\section{TOTAL COMMUNITY DNA}

The total DNA from manure was the same as used by Binh et al. (2008, 2009). Total DNA from soil samples (soils sieved through a $2 \mathrm{~mm}$ mesh size) was extracted using the FastPrep FP120 bead beating system for cell lysis in conjunction with the FastDNA SPIN Kit for Soil, and the GeneClean Spin Kit for purification of the extracted DNA (Qbiogene, Carlsbad, CA, USA).

\section{QUANTITATIVE PCR TARGETING IncP-1ع PLASMIDS OR 16S rRNA GENES}

Ribosomal gene targets in total DNA were quantified by $5^{\prime}$-nuclease assays in real-time PCR as previously described (Suzuki et al., 2000; Heuer and Smalla, 2007). Analogously,

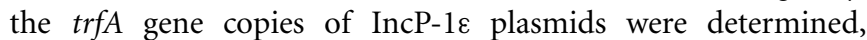
using primers trfA 9 941f (ACGAAGAAATGGTTGTCCTGTTC), $\operatorname{trfA} \varepsilon 1014$ r (CGTCAGCTTGCGGTACTTCTC), and the Taqman probe trfA\&965tp (FAM-CCGGCGACCATTACAGCAAGTTCAT TT-TAMRA). Standard dilutions were generated from a gelpurified PCR product of the $281 \mathrm{bp}$ trfA fragment amplified from plasmid pHH3408 using previously described primers (Bahl et al., 2009). Quantitative PCR was performed in a CFX96 real-time PCR detection system (Bio-Rad, Munich, Germany). PCR reactions contained standard or environmental DNA, 1.25 U TrueStart Taq DNA polymerase and buffer (Fermentas, St. Leon-Rot, Germany), $0.2 \mathrm{mM}$ of each deoxynucleoside triphosphate, $2.5 \mathrm{mM}$ $\mathrm{MgCl}_{2}, 0.1 \mathrm{mg} \mathrm{ml}^{-1} \mathrm{BSA}$, and $0.3 \mu \mathrm{M}$ of primers and probe in $50 \mu \mathrm{l}$. Thermocycles were $5 \mathrm{~min} 95^{\circ} \mathrm{C}$, and 40 cycles consisting of $15 \mathrm{~s} 95^{\circ} \mathrm{C}$ and $60 \mathrm{~s} 60^{\circ} \mathrm{C}$. Effects of manure and SDZ on the relative abundance of IncP- $1 \varepsilon$ plasmids in soil were analyzed by ANOVA using the procedure MIXED for repeated-measures comparison included in the statistical software package SAS 9.2 (SAS Institute, Cary, NC, USA).

\section{SEQUENCE ANALYSIS}

Sequencing of shotgun libraries from the plasmids, sequence assembly, and gap closure by primer walking were performed by the U.S. Department of Energy Joint Genome Institute (Walnut Creek, CA, USA). Automatic annotation was carried out by the J. Craig Venter Institute Annotation Service ${ }^{1}$ followed by manual annotation. Similarities of the plasmid sequences to other plasmids, transposons, IS elements, and integrons were found by BLASTN searches of GenBank ${ }^{2}$. Putative open reading frames in the complete nucleotide sequences were compared by BLASTN searches to GenBank sequences. Additional searches for genes, operons, promoters, and terminators were done using FGENESB, BPROM, and FindTerm at www.softberry.com (Softberry, Mount Kisco, NY, USA). The sequence data have been submitted to the DDBJ/EMBL/GenBank databases under accession numbers JQ004406-JQ004409.

\section{RESULTS \\ ABUNDANCE OF IncP-1 1 PLASMIDS IN BACTERIAL COMMUNITIES OF MANURE AND SOIL}

To quantify IncP- $1 \varepsilon$ plasmids in total community DNA from manure and soil samples, a $5^{\prime}$-nuclease assay for real-time PCR specifically targeting the replication initiation gene $\operatorname{trf} A$ of these plasmids $(r f A \varepsilon)$ was developed and applied. The abundance of the $\operatorname{tr} A \varepsilon$ gene in total DNA from manure relative to the $r r n$ copy number varied from $10^{-1}$ to $10^{-5}$ (Table 1). A higher relative abundance of the $\operatorname{trfA\varepsilon }$ gene was observed in total DNA from manure obtained from pig producing facilities with large numbers of pigs, high-throughput piglet production, or documented usage of several antibiotic compounds (Table 1). In these farms, a high antibiotic usage is typical because of metaphylactic application in large herds and prophylactic application at weaning of

\footnotetext{
${ }^{1} \mathrm{http} / /$ www.jcvi.org/cms/research/projects/annotation-service/overview/

${ }^{2}$ http://ncbi.nlm.nih.gov
}

Table 1 | Abundance of IncP-1 $\varepsilon$ plasmids in field-scale manures from different pig production facilities.

\begin{tabular}{|c|c|c|c|}
\hline No. & Farm size and type of pig production & Antibiotic usage & $\begin{array}{l}\text { IncP-1 } \varepsilon \text { plasmids } \\
\text { log[copies } \operatorname{trf} A \varepsilon / r r n]\end{array}$ \\
\hline 9 & 2000 pigs, $30-120$ kg, 700 g/day increase, slatted floor & High (amoxicillin, doxycycline): large herd & -0.8 \\
\hline 8 & 300 sows, 6900 piglets/year, slatted floor & High: frequent weaning & -1.3 \\
\hline 15 & 1800 pigs, $25-123 \mathrm{~kg}, 660 \mathrm{~g} /$ day increase, slatted floor & High (tylosin, penicillin): large herd & -1.4 \\
\hline 3 & 80 sows, 1520 piglets/year & $\begin{array}{l}\text { High (amoxicillin, penicillin, neomycin, tylosin, enrofloxacin, } \\
\text { apramycin): weaning }\end{array}$ & -1.5 \\
\hline 10 & 1300 pigs, $30-125$ kg, 700 g/day increase, slatted floor & Medium (amoxicillin, enrofloxacin) & -2.1 \\
\hline 7 & 600 pigs, $30-125 \mathrm{~kg}, 750 \mathrm{~g} /$ day increase, partly slatted floor & $\begin{array}{l}\text { Medium (gentamicin, tylosin, tetracycline, lincomycin): } \\
\text { prophylactic for new piglets }\end{array}$ & -2.2 \\
\hline 6 & 1800 pigs, $8-140$ kg, 800 g/day increase & Medium (amoxicillin, tetracycline): large herd, long life cycle & -2.6 \\
\hline 12 & Meat-production pigs, $30-120 \mathrm{~kg}, 650 \mathrm{~g} /$ day increase & Unknown & -2.8 \\
\hline 4 & 80 sows, 1600 piglets/year & $\begin{array}{l}\text { Medium (tulathromycin, streptomycin, tetracycline, } \\
\text { enrofloxacin) }\end{array}$ & -3.2 \\
\hline 13 & 550 pigs, $32-110 \mathrm{~kg}, 550 \mathrm{~g} /$ day increase, partly slatted floor & No antibiotics used & -5.2 \\
\hline
\end{tabular}


piglets. In contrast, manure from small pig producing facilities had up to four orders of magnitude lower abundances of IncP-1ع plasmids, especially farm no. 13 which did not apply any antibiotic compounds recently. The correlation of plasmid abundance with antibiotic usage suggested that these plasmids from manure typically carry accessory antibiotic resistance genes. We investigated whether manure application on agricultural soil could increase the abundance of resistance plasmids in the environment.

In a microcosm experiment, addition of antibiotic-free manure or the antibiotic SDZ to arable soil did not increase the level of IncP- $1 \varepsilon$ plasmids compared to untreated soil (Figure 1). However, when manure was added to soil that was spiked with SDZ at a concentration typical for manure from SDZ-treated pigs, the abundance of IncP- $1 \varepsilon$ plasmids was significantly increased compared to the other treatments (two-way ANOVA, $P=0.025$ ). This indicated a synergistic effect of manure and SDZ causing an enrichment of bacteria that carry sulfonamide resistance conferring IncP- $1 \varepsilon$ plasmids within the soil community. An accumulation of these plasmids due to the repeated treatment was not observed. In three different agricultural soils from an experimental plot that had only received mineral fertilizer for more than 10 years, the abundance of the $\operatorname{trfA\varepsilon }$ gene relative to the $r r n$ copy number varied around $10^{-5}$ (data not shown).

\section{CAPTURING IncP-1 $\varepsilon$ PLASMIDS FROM MANURE TREATED SOIL}

Fifty conjugative plasmids that were exogenously captured from manure, bulk soil, and rhizosphere bacteria into E. coli CV601gfp based on the acquired SDZ resistance were assigned to IncP-1E based on DNA-hybridization with a pKJK5 derived $\operatorname{trfA}$ probe or by means of the IncP- $1 \varepsilon$ specific real-time PCR. The isolation of IncP- $1 \varepsilon$ plasmids from independent microcosms, mesocosms, and field experiments indicated a widespread dissemination of IncP- $1 \varepsilon$

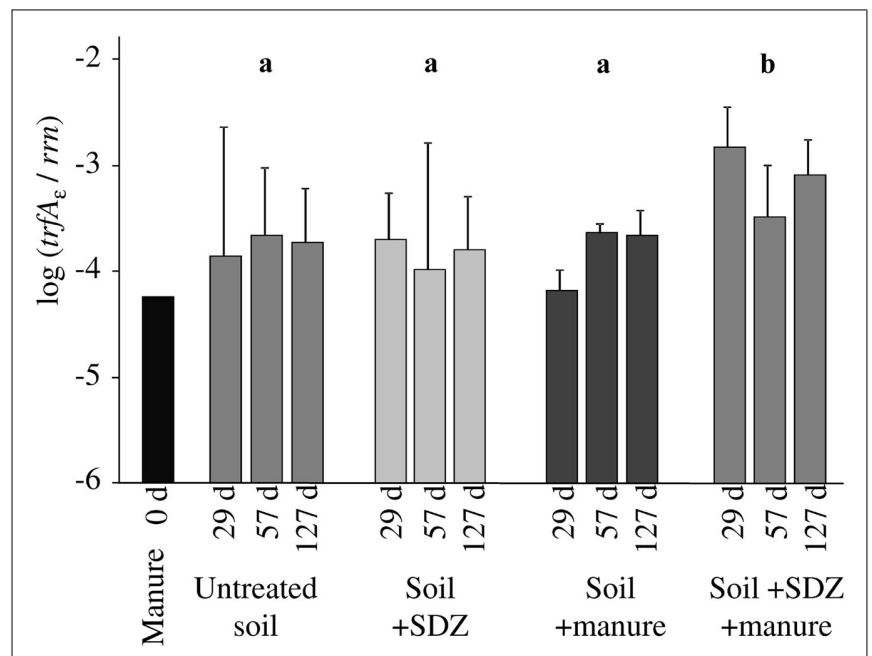

FIGURE 1 | Copy numbers of trfA (replication initiation gene) of IncP-1 $\varepsilon$ plasmids relative to 16S rRNA gene copies (rrn) in manure and in soil, which was treated either with the antibiotic compound sulfadiazine (SDZ), with manure without antibiotics, with manure containing SDZ, or with water (untreated). Sampling of the soil microcosms was repeated three times. Error bars indicate SD $(n=4)$. Differing letters show a significant effect of the treatment (ANOVA with repeated measures). plasmids in agricultural soils. In all IncP- $1 \varepsilon$ plasmids the SDZ resistance gene sull and the integrase gene intI1 of class 1 integrons were detected (Table 2). PCR amplification with primers targeting the regions flanking class 1 integrons revealed that three plasmids carried empty integrons (size of the fragment $300 \mathrm{bp}$ ) while all others carried gene cassettes of different sizes ranging from 500 to 4000 bp (Table 2). Southern blot hybridization of PCR amplified gene cassettes showed that 30 IncP- $1 \varepsilon$ carried the aadA gene. The complete sequence of four of the plasmids was determined.

\section{HOST RANGE}

To investigate the host range of IncP-1 $1 \varepsilon$ plasmids, E. coli CV601gfp carrying pHH3414 was introduced into soil microcosms planted with $A$. caven. PCR screening of $30 \mathrm{gfp}$ negative bacteria from the rhizosphere of $A$. caven grown on selective media for resistances conferred by $\mathrm{pHH} 3414$ resulted in six IncP-1e positive isolates. BOX-PCR revealed that the transconjugants exhibited four different BOX patterns that were clearly distinct from BOX patterns of the donor E. coli CV601gfp pHH3414. The SphI restriction patterns of plasmid DNA isolated from putative transconjugants were identical to the restriction patterns of plasmid pHH3414. Partial sequencing of the 16S rRNA gene of the transconjugants showed that they were affiliated to Beta- and Gammaproteobacteria. Three isolates displayed the highest sequence similarity to Enterobacter amnigenus (758/759). The 16S rRNA gene sequence of the other isolates had the highest sequence similarity to Xanthomonas codiaei (618/621), Cupriavidus campinensis (789/789), and Alcaligenes sp. $(793 / 797)$.

\section{COMPLETE SEQUENCE OF IncP-1£ PLASMIDS}

The complete genome sequences of four IncP- $1 \varepsilon$ plasmids that conferred sulfonamide resistance (pKS77, pHH3414, pHH128, and $\mathrm{pHH} 3408$ ) were obtained and analyzed. Plasmids pHH128, pHH3408, and pHH3414 originated from an arable field soil near Kaldenkirchen (Germany), and were captured 8, 57, or 85 days after manure application, respectively. Plasmid pKS77 was exogenously isolated from pig manure. The backbone of all four plasmids was $99.9 \%$ identical to that of pKJK5, the first published complete sequence of the IncP-1 $1 \varepsilon$ plasmids (Figure 2). It comprised genetic modules for replication, partitioning and regulation, mating pair formation and conjugative transfer, and a region with genes of unknown function. In all four plasmids two accessory regions were inserted into the $5^{\prime}$ part of parA, which was partially deleted and may not be functional. The identity of backbones and insertion sites among the plasmids suggested a very recent spread from a common ancestor. One of the insertions in all the plasmids is similar to the IS-element ISPa 17 (Figure 3). The flanking $25 \mathrm{bp}$ inverted repeats are the targets for the transposase tnpA, and the $6 \mathrm{bp}$ direct repeats generated during transposition are still present in all the plasmids. The second insertion site in parA contains a Tn402-related transposon that carries the ISelement IS1326 and a class 1 integron. The plasmids differ in the gene cassettes that were captured into the attachment site of the integron. They harbor aadA (pHH3414), aadB (pKS77), or aadA1b, $d f r A 1 b$, and two copies of $c a t B$ ( $\mathrm{pHH} 128$ ), or were devoid of any gene cassette (pHH3408). The sul1 gene in the $3^{\prime}$ conserved segment of the integrons conferred sulfonamide resistance. 
Table 2 | Characterization of exogenously isolated IncP-1 $\varepsilon$ plasmids from agro-ecosystems.

\begin{tabular}{|c|c|c|c|}
\hline Plasmid & Source & $\begin{array}{l}\text { PCR product with primers } \\
\text { targeting } 5^{\prime} / 3^{\prime} \mathrm{CS} \text { of } \\
\text { integron (kbp) }\end{array}$ & $\begin{array}{l}\text { Hybridization } \\
\text { with aadA }\end{array}$ \\
\hline $2-S 2$ & Manure 2 & 1.0 & + \\
\hline 2-S5 & Manure 2 & 1.5 & + \\
\hline 3-S1 & Manure 3 & 1.0 & + \\
\hline 4-T4 & Manure 4 & 2.0 & + \\
\hline $6-\$ 1$ & Manure 6 & 1.0 & - \\
\hline 7-S & Manure 7 & 1.0 & + \\
\hline 9-T4 & Manure 9 & 1.3 & - \\
\hline $11-S 2$ & Manure 11 & 1.0 & + \\
\hline $1-83$ & Soil microcosm & 1.0 & + \\
\hline $1-91$ & Soil microcosm & 5 & - \\
\hline 1-111 & Soil microcosm & 1.6 & + \\
\hline $1-115$ & Soil microcosm & 3 & - \\
\hline $1-127$ & Soil microcosm & 1.3 & - \\
\hline $1-131$ & Soil microcosm & $1.7 / 2.3$ & + \\
\hline $1-135$ & Soil microcosm & 5 & - \\
\hline $1-146$ & Soil microcosm & 5 & - \\
\hline $1-153$ & Soil microcosm & 5 & - \\
\hline $1-163$ & Soil microcosm & $2.0 / 4$ & + \\
\hline $1-167$ & Soil microcosm & 5 & - \\
\hline $1-168$ & Soil microcosm & 5 & - \\
\hline $2-238$ & Soil microcosm & 5 & - \\
\hline 3-385 & Soil microcosm & 5 & - \\
\hline $3-407$ & Soil microcosm & 3 & - \\
\hline $3-409$ & Soil microcosm & 1.0 & + \\
\hline $3-420$ & Soil microcosm & 2.1 & + \\
\hline $3-422$ & Soil microcosm & 2.1 & + \\
\hline $3-423$ & Soil microcosm & 2.1 & + \\
\hline $3-425$ & Soil microcosm & 2.1 & + \\
\hline $3-426$ & Soil microcosm & 2.1 & + \\
\hline $3-427$ & Soil microcosm & 2.1 & + \\
\hline $3-428$ & Soil microcosm & 2.1 & + \\
\hline C 66 & Soil mesocosm & 1.8 & - \\
\hline C 120 & Soil mesocosm & 2.1 & + \\
\hline C 126 & Soil mesocosm & 2.3 & + \\
\hline C 129 & Soil mesocosm & 5 & - \\
\hline C 131 & Soil mesocosm & $3.0 / 2.1$ & + \\
\hline C 132 & Soil mesocosm & 2.1 & + \\
\hline C 159 & Soil mesocosm & 5 & - \\
\hline 144 & Field soil & $1.4 / 2.9 / 3.5$ & + \\
\hline 253 & Field soil & 1.3 & - \\
\hline 260 & Field soil & 5 & - \\
\hline 263 & Field soil & $1.4 / 2.9 / 3.5$ & + \\
\hline 267 & Field soil & 2.1 & + \\
\hline 268 & Field soil & $1.4 / 2.1 / 2.9$ & + \\
\hline 269 & Field soil & 5 & - \\
\hline 858 & Field soil & 1.2 & + \\
\hline 972 & Field soil & 1.1 & + \\
\hline
\end{tabular}

The transposition modules tniABQC (Rådström et al., 1994) of the Tn402-like transposons were $3^{\prime}$ truncated to a different

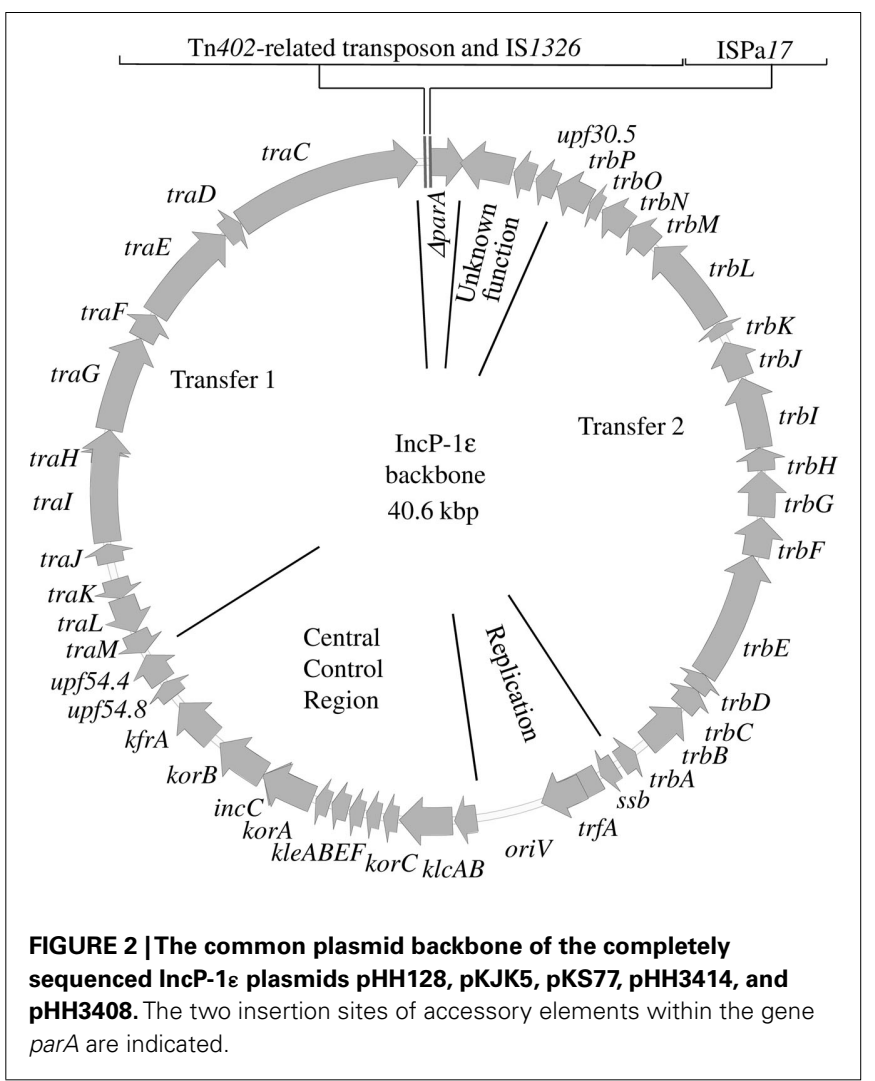

extent, and replaced by a more or less truncated derivative of the tetracycline resistance transposon $\operatorname{Tn} 1721$, except for plasmid pHH3408 (Figure 3). All Tn402-related transposons were flanked by inverted and direct repeats. Interestingly, a fragment of the IncP- $1 \alpha$ ori $V$ was found in plasmid pHH128 and pKS77 adjacent to IS1326, suggesting recombination between these incompatible plasmids.

\section{DISCUSSION}

Independent isolations of IncP- $1 \varepsilon$ plasmids and their detection in total community DNA by quantitative PCR showed that these plasmids are widely distributed in agricultural soils and pig manure. Previous attempts to detect IncP-1 plasmids in total community DNA from various environments must have missed this plasmid group as the $\operatorname{trf} A$ sequence of IncP-1 $1 \varepsilon$ plasmids shared less than $75 \%$ sequence identity in the region used for probes generated from RP4 or R751 (Götz et al., 1996). The present study adds 50 novel plasmids to this subgroup which was previously proposed by Bahl et al. (2009) based on two representatives. Very recently, three other IncP-1 $1 \varepsilon$ plasmids exogenously isolated from Norwegian agricultural soils were completely sequenced (Sen et al., 2011). In contrast to the completely sequenced plasmids of our study, the backbone genes of the Norwegian plasmids were considerably divergent from those of the reference plasmid pKJK5. They did not carry integrons, while on all exogenously isolated plasmids of the present study class 1 integron components (intI1, sull, gene cassettes) were detected. With the exception of plasmid pKS77, all plasmids were captured based on the SDZ resistance conferred to 


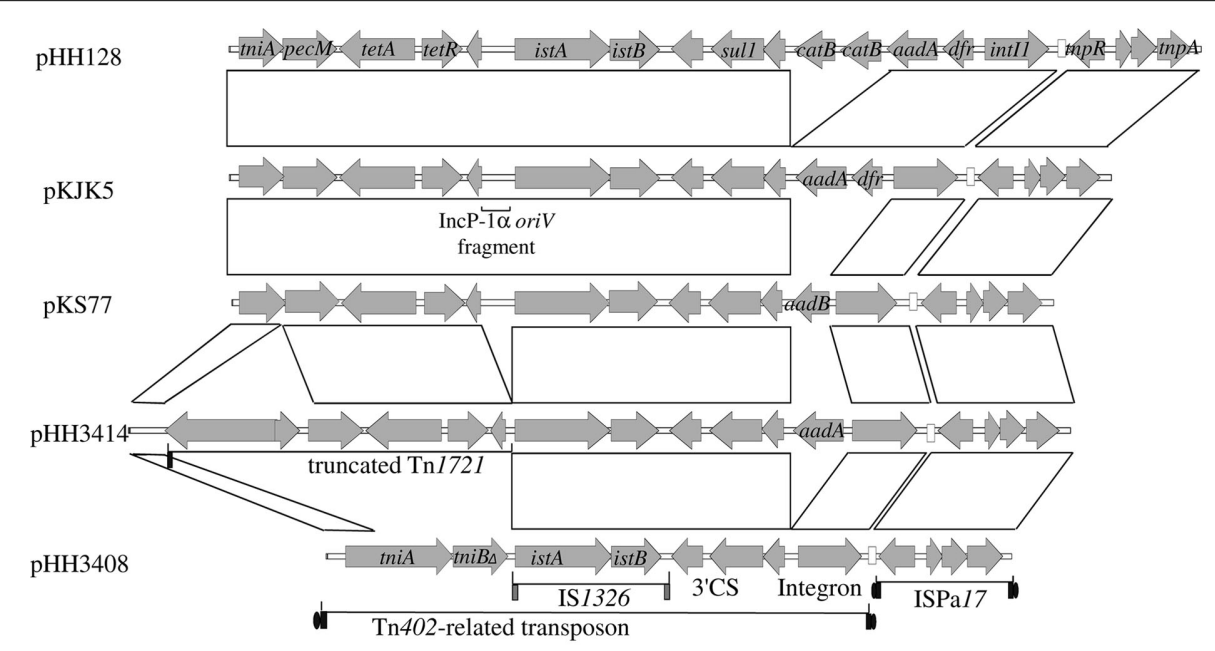

FIGURE 3 | Accessory regions of the completely sequenced IncP-1 $\varepsilon$ plasmids pHH128, pKJK5, pKS77, pHH3414, and pHH3408. Homologous regions are indicated by framed areas. Inverted repeats of the transposable elements are indicated by rectangles, target site duplications (direct repeats) are indicated by closed ovals.

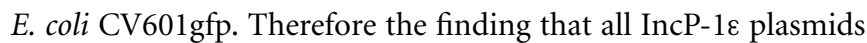
carried a class 1 integron might be not too surprising as these integrons often carry a sull gene. In contrast, the Norwegian plasmids were captured based on the mercury resistance that they confer to the recipient (Sen et al., 2011).

Although restriction analysis of plasmid DNA indicated a remarkable diversity of the plasmids captured in our study, the complete sequence determined for four of the plasmids showed that the backbones comprising modules for replication, partitioning and regulation, mating pair formation and conjugative transfer, and a region of unknown function were almost identical with the backbone sequence of the reference plasmid pKJK5. The identity of the backbone and of insertion sites suggested a very recent spread from a common ancestor. As previously reported for $\mathrm{pKJK} 5$, a fragment of the IncP- $1 \alpha$ oriV was found in plasmid pHH128 and pKS77 adjacent to IS1326, indicating recombination between incompatible plasmids. This finding is in agreement with other evidence in IncP-1 genome sequences that recombination between IncP-1 plasmids is occurring despite incompatibility (Schlüter et al., 2003; Norberg et al., 2011).

One of the drawbacks of exogenous isolation directly from soil bacteria is that the original hosts remain unknown. Therefore, $E$. coli CV601gfp carrying plasmid pHH3414 was introduced into soil planted with A. caven. The soil was amended with manure to stimulate plasmid transfer processes. Plasmid pHH3414 was chosen as the level of soil bacteria resistant toward tetracycline and SDZ was relatively low. After 4 weeks the numbers of the $g f p$-tagged $E$. coli significantly dropped and $g f p$ negative colonies with Tc and SDZ phenotype could be picked. Although only cultivable hosts of IncP- $1 \varepsilon$ plasmids can be identified using this strategy stable replication is a prerequisite for detection. The host range determined in the rhizosphere of A. caven for pHH3414 was mainly confined to Beta- and Gammaproteobacteria and thus confirms the host range suggested for IncP-1 plasmids by analyzing the genomic signatures for host identification (Suzuki et al., 2010; Norberg et al.,
2011). Several other strategies were previously used to determine the host range of plasmid pKJK5. Tagging of both the donor and the plasmids allowed a cultivation-independent quantification of donors and transconjugants (Mølbak et al., 2003). In another study by Mølbak et al. (2007) transconjugants mainly belonged to the family Enterobacteriaceae or the genus Pseudomonas. In order to determine the host range of $\mathrm{pKJK} 5$ in the rhizosphere of barley, Musovic et al. (2006) inoculated Pseudomonas putida harboring $l a c \mathrm{I}_{\mathrm{q}}$ with a $g f p$-tagged $\mathrm{pKJK} 5$. Transconjugants were obtained after sorting by flow cytometry. The identity of putative transconjugants was determined by cloning and sequencing,

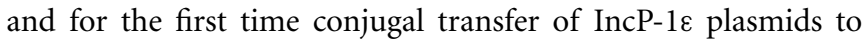
Gram-positive bacteria was documented (Arthrobacter). As the transconjugants have not been cultured, the potential of IncP- $1 \varepsilon$ plasmids to replicate in Arthrobacter still needs to be confirmed. Differences in the spectrum of hosts reported for IncP- $1 \varepsilon$ plasmids might be explained by differences in bacterial community composition, but the detection methods are also assumed to have an effect. While homologous recombination might play an important role in the adaptation to different host backgrounds, class 1 integron gene cassettes seem to be important drivers of diversification to selective pressure posed by antibiotics. This assumption is further supported by the recent report by Guerin et al. (2009) on the induction of SOS response by antibiotic exposure, and a 340 times increase of gene cassette excision and integration might be of great importance. Several studies recently showed that class 1 integron gene cassettes were introduced via manure bacteria into soil (Binh et al., 2009; Byrne-Bailey et al., 2009, 2010). The localization of class 1 integrons on the broad-host range plasmids belonging to the IncP- $1 \varepsilon$ group further emphasizes their mobility potential. Interestingly, several of the gene cassettes previously reported from manure or manure treated soil, such as aadA, aadB, or orfD (Heuer and Smalla, 2007; Binh et al., 2009) were also found on IncP-1ع plasmids. But in contrast to the total community DNA analysis the size of the amplified gene cassettes was larger than $1.6 \mathrm{~kb}$. 
This might indicate a bias of the PCR-based amplification of class 1 integron gene cassettes from total community DNA approach toward smaller fragments.

Plasmids belonging to the IncP- $1 \varepsilon$ group were captured into E. coli from soil bacteria in independent experiments. Although the relative abundance of IncP- $1 \varepsilon$ plasmids as determined by realtime quantitative PCR is relatively low and thus would not be accessible by metagenomic approaches, the ability of these plasmids to efficiently transfer allowed their capture by exogenous plasmid isolation. Furthermore, the novel trfA based quantitative PCR system provided a tool to quantify IncP- $1 \varepsilon$ plasmid abundance in total community DNA which showed a correlation between plasmid abundance and antibiotic selective pressure. In piggery manures, the relative abundance of IncP- $1 \varepsilon$ was found to be high and seemed to be correlated with the size and antibiotic usage of the pig producing facility. Interestingly the lowest abundance of plasmids belonging to the IncP- $1 \varepsilon$ group was found in manure from a pig producing facility that never used antibiotics.

\section{REFERENCES}

Bahl, M. I., Burmolle, M., Meisner, A., Hansen, L. H., and Sorensen, S. J. (2009). All IncP-1 plasmid subgroups, including the novel epsilon subgroup, are prevalent in the influent of a Danish wastewater treatment plant. Plasmid 62, 134-139.

Bahl, M. I., Hansen, L. H., Goesmann, A., and Sorensen, S. J. (2007). The multiple antibiotic resistance IncP1 plasmid pKJK5 isolated from a soil environment is phylogenetically divergent from members of the previously established alpha, beta and delta sub-groups. Plasmid 58, 31-43.

Binh, C. T. T., Heuer, H., Gomes, N. C. M., Kotzerke, A., Fulle, M., Wilke, B. M., Schloter, M., and Smalla, K. (2007). Short-term effects of amoxicillin on bacterial communities in manured soil. FEMS Microbiol. Ecol. 62, 290-302.

Binh, C. T. T., Heuer, H., Kaupenjohann, M., and Smalla, K. (2008). Piggery manure used for soil fertilization is a reservoir for transferable antibiotic resistance plasmids. FEMS Microbiol. Ecol. 66, 25-37.

Binh, C. T. T., Heuer, H., Kaupenjohann, M., and Smalla, K. (2009). Diverse aadA gene cassettes on class 1 integrons introduced into soil via spread manure. Res. Microbiol. 160, 427-433.

Byrne-Bailey, K. G., Gaze, W. H., Kay, P., Boxall, A. B., Hawkey, P. M., and Wellington, E. M. H. (2009). Prevalence of sulfonamide resistance genes in bacterial isolates from manured agricultural soils and pig slurry in the United Kingdom. Antimicrob. Agents Chemother. 53, 696-702.
Byrne-Bailey, K. G., Gaze, W. H., Zhang, L., Kay, P., Boxall, A. B., Hawkey, P. M., and Wellington, E. M. H. (2010). Integron prevalence and diversity in manured soil. Appl. Environ. Microbiol. 77, 684-687.

Couturier, M., Bex, F., Bergquist, P. L., and Maas, W. K. (1988). Identification and classification of bacterial plasmids. Microbiol. Rev. 52, 375-395.

Götz, A., Pukall, R., Smit, E., Tietze, E., Prager, R., Tschäpe, H., van Elsas, J. D., and Smalla, K. (1996). Detection and characterization of broadhost-range plasmids in environmental bacteria by PCR. Appl. Environ. Microbiol. 62, 2621-2628.

Guerin, É., Cambray, G., SanchezAlberola, N., Campoy, S., Erill, I., Da Re, S., Gonzalez-Zorn, B., Barbé, J., Ploy, M. C., and Mazel, D. (2009). The SOS response controls integron recombination. Science 324, 1034.

Haines, A. S., Akhtar, P., Stephens, E. R., Jones, K., Thomas, C. M., Perkins, C. D., Williams, J. R., Day, M. J., and Fry, J. C. (2006). Plasmids from freshwater environments capable of lncQ retrotransfer are diverse and include pQKH54, a new lncP-1 subgroup archetype. Microbiology 152, 2689-2701.

Heuer, H., Krögerrecklenfort, E., Wellington, E. M. H., Egan, S., van Elsas, J. D., van Overbeek, L. S., Collard, J. M., Guillaume, G., Karagouni, A. D., Nikolakopoulou, T. L., and Smalla, K. (2002). Gentamicin resistance genes in environmental bacteria: prevalence and transfer. FEMS Microbiol. Ecol. 42, 289-302.

Heuer, H., Schmitt, H., and Smalla, K. (2011). Antibiotic resistance gene

The remarkable diversity of antibiotic resistance gene cassettes reported in the present study, the ability to efficiently transfer under soil conditions and the wide host range of IncP-1 $1 \varepsilon$ plasmids strongly suggest that these plasmids are important vectors for spreading antibiotic resistances in the agro-ecosystem.

\section{ACKNOWLEDGMENTS}

This work was supported by the DFG, in the frame of the project "Veterinary Medicines in Soils" (Forschergruppe 566), and by grant EF-0627988 from the NSF Microbial Genome Sequencing Program to Eva Top. We are grateful to the US Department of Energy Joint Genome Institute for providing the draft plasmid genome sequences (with special thanks to Brian Foster, Alla Lapidus, and Kerry Barrie). Their work was supported by the Office of Science of the US Department of Energy under Contract No. DE-AC02-05CH11231. We also thank Celeste Brown for Bioinformatics support and Linda Rogers for technical assistance.

spread due to manure application on agricultural fields. Curr. Opin. Microbiol. 14, 236-243.

Heuer, H., and Smalla, K. (2007). Manure and sulfadiazine synergistically increased bacterial antibiotic resistance in soil over at least two months. Environ. Microbiol. 9, 657-666.

Mølbak, L., Licht, T. R., Kvist, T., Kroer, N., and Andersen, S. R. (2003). Plasmid transfer from Pseudomonas putida to the indigenous bacteria on alfalfa sprouts: characterization, direct quantification, and in situ location of transconjugant cells. Appl. Environ. Microbiol. 69, 5536-5542.

Mølbak, L., Molin, S., and Kroer, N. (2007). Root growth and exudate production define the frequency of horizontal plasmid transfer in the rhizosphere. FEMS Microbiol. Ecol. 59, 167-176.

Moura, A., Henriques, I., Smalla, K., and Correia, A. (2010). Wastewater bacterial communities bring together broad-host range plasmids, integrons and a wide diversity of uncharacterized gene cassettes. Res. Microbiol. 161, 58-66.

Musovic, S., Oregaard, G., Kroer, N., and Sorensen, S. J. (2006). Cultivationindependent examination of horizontal transfer and host range of an IncP-1 plasmid among Grampositive and Gram-negative bacteria indigenous to the barley rhizosphere. Appl. Environ. Microbiol. 72, 6687-6692.

Norberg, P., Bergström, M., Jethava, V., Dubhashi, D., and Hermansson, M. (2011). The IncP-1 plasmid backbone adapts to different host bacterial species and evolves through homologous recombination. Nat. Commun. 2, 268.

Pansegrau, W., Lanka, E., Barth, P. T., Figurski, D. H., Guiney, D. G., Haas, D., Helinski, D. R., Schwab, H., Stanisich, V. A., and Thomas, C. M. (1994). Complete nucleotide sequence of Birmingham IncP-alpha plasmids - compilation and comparative analysis. J. Mol. Biol. 239, 623-663.

Rådström, P., Sköld, O., Swedberg, G., Flensburg, J., Roy, P. H., and Sundström, L. (1994). Transposon Tn5090 of plasmid R751, which carries an integron, is related to $\mathrm{Tn} 7$, $\mathrm{Mu}$, and the retroelements. J. Bacteriol. 176, 3257-3268.

Schauss, K., Focks, A., Heuer, H., Kotzerke, A., Schmitt, H., ThieleBruhn, S., Smalla, K., Wilke, B. M., Matthies, M., Amelung, W., Klasmeier, J., and Schloter, M. (2009). Analysis, fate and effects of the antibiotic sulfadiazine in soil ecosystems. Trends Anal. Chem. 28, 612-618.

Schlüter, A., Heuer, H., Szczepanowski, R., Forney, L. J., Thomas, C. M., Pühler, A., and Top, E. M. (2003). The 64508 bp IncP-1 $\beta$ antibiotic multiresistance plasmid pB10 isolated from a waste-water treatment plant provides evidence for recombination between members of different branches of the IncP- $1 \beta$ group. Microbiology 149, 3139-3153.

Schlüter, A., Szczepanowski, R., Pühler, A., and Top, E. M. (2007). Genomics of IncP-1 antibiotic resistance plasmids isolated from wastewater treatment plants provides evidence for a widely accessible drug resistance gene pool. FEMS Microbiol. Rev. 31, 449-477. 
Sen, D., Van der Auwera, G. A., Rogers, L. M., Thomas, C. M., Brown, C. J., and Top, E. M. (2011). Broad-host-range plasmids from agricultural soils have IncP-1 backbones with diverse accessory genes. Appl. Environ. Microbiol. 77, 7975-7983.

Smalla, K., Haines, A. S., Jones, K., Krögerrecklenfort, E., Heuer, H., Schloter, M., and Thomas, C. M. (2006). Increased abundance of IncP-1 $\beta$ plasmids and mercury resistance genes in mercurypolluted river sediments: first discovery of IncP-1 $\beta$ plasmids with a complex mer transposon as the sole accessory element. Appl. Environ. Microbiol. 72, 7253-7259.

Smalla, K., Krögerrecklenfort, E., Heuer, H., Dejonghe, W., Top, E., Osborn, M., Niewint, J., Tebbe, C., Barr, M., Bailey, M., Greated, A., Thomas, C., Turner, S., Young, P., Nikolakopoulou, D., Karagouni, A.,
Wolters, A., van Elsas, J. D., Dronen, K., Sandaa, R., Borin, S., Brabhu, J., Grohmann, E., and Sobecky, P. (2000). PCR-based detection of mobile genetic elements in total community DNA. Microbiology 146, 1256-1257.

Suzuki, H., Yano, H., Brown, C. J., and Top, E. M. (2010). Predicting plasmid promiscuity based on genomic signature. J. Bacteriol. 192, 6045-6055.

Suzuki, M. T., Taylor, L. T., and Delong, E. F. (2000). Quantitative analysis of small-subunit rRNA genes in mixed microbial populations via $5^{\prime}$-nuclease assays. Appl. Environ. Microbiol. 66, 4605-4614.

Thomas, C. M. (2000). Paradigms of plasmid organization. Mol. Microbiol. 37, 485-491.

Thorsted, P. A., Macartney, D. P., Akhtar, P., Haines, A. S., Ali, N., Davidson, P., Stafford, T., Pocklington, M.
J., Pansegrau, W., Wilkins, B. M., Lanka, E., and Thomas, C. N. (1998). Complete sequence of the IncP beta plasmid R751: implications for evolution and organisation of the IncP backbone. J. Mol. Biol. 282, 969-990.

Vedler, E., Vahter, M., and Heinaru, A. (2004). The completely sequenced plasmid pEST4011 contains a novel IncP1 backbone and a catabolic transposon harboring $t f d$ genes for 2,4-dichlorophenoxyacetic acid degradation. J. Bacteriol. 186, 7161-7174.

Conflict of Interest Statement: The authors declare that the research was conducted in the absence of any commercial or financial relationships that could be construed as a potential conflict of interest.

Received: 15 November 2011; paper pending published: 18 December 2011; accepted: 02 January 2012; published online: 18 January 2012.

Citation: Heuer H, Binh CTT, Jechalke $S$, Kopmann C, Zimmerling U, Krögerrecklenfort E, Ledger T, González B, Top $E$ and Smalla $K$ (2012) IncP-1e plasmids are important vectors of antibiotic resistance genes in agricultural systems: diversification driven by class 1 integron gene cassettes. Front. Microbio. 3:2. doi: 10.3389/fmicb.2012.00002

This article was submitted to Frontiers in Antimicrobials, Resistance and Chemotherapy, a specialty of Frontiers in Microbiology.

Copyright (c) 2012 Heuer, Binh, Jechalke, Kopmann, Zimmerling, Krögerrecklenfort, Ledger, González, Top and Smalla. This is an open-access article distributed under the terms of the Creative Commons Attribution Non Commercial License, which permits non-commercial use, distribution, and reproduction in other forums, provided the original authors and source are credited. 